Research article

\title{
Chemically induced DNA hypomethylation in breast carcinoma cells detected by the amplification of intermethylated sites
}

\author{
Bekim Sadikovic, Thomas R Haines, Darci T Butcher and David I Rodenhiser
}

\author{
The London Regional Cancer Centre, London Health Sciences Centre, Child Health Research Institute, and the Departments of Biochemistry, \\ Paediatrics and Oncology, at the University of Western Ontario, London, Ontario, Canada \\ Corresponding author: David I Rodenhiser, drodenhi@uwo.ca
}

Received: 26 Nov 2003 Revisions requested: 26 Jan 2004 Revisions received: 10 Feb 2004 Accepted: 31 Mar 2004 Published: 30 Apr 2004

Breast Cancer Res 2004, 6:R329-R337 (DOI 10.1186/bcr799)

(c) 2004 Sadikovic et al.; licensee BioMed Central Ltd. This is an Open Access article: verbatim copying and redistribution of this article are permitted in all media for any purpose, provided this notice is preserved along with the article's original URL.

\begin{abstract}
Introduction Compromised patterns of gene expression result in genomic instability, altered patterns of gene expression and tumour formation. Specifically, aberrant DNA hypermethylation in gene promoter regions leads to gene silencing, whereas global hypomethylation events can result in chromosomal instability and oncogene activation. Potential links exist between environmental agents and DNA methylation, but the destabilizing effects of environmental exposures on the DNA methylation machinery are not understood within the context of breast cancer aetiology.

Methods We assessed genome-wide changes in methylation patterns using a unique methylation profiling technique called amplification of intermethylated sites (AIMS). This method generates easily readable fingerprints that represent the investigated cell line's methylation profile, based on the differential cleavage of DNA with methylation-specific isoschisomeric restriction endonucleases.
\end{abstract}

\begin{abstract}
Results We validated this approach by demonstrating both unique and reoccurring sites of genomic hypomethylation in four breast carcinoma cell lines treated with the cytosine analogue 5azacytidine. Comparison of treated with control samples revealed individual bands that exhibited methylation changes, and these bands were excized and cloned, and the precise genomic location individually identified. In most cases, these regions of hypomethylation coincided with susceptible target regions previously associated with chromosome breakage, rearrangement and gene amplification. Similarly, we observed that acute benzopyrene exposure is associated with altered methylation patterns in these cell lines.
\end{abstract}

Conclusion These results reinforce the link between environmental exposures, DNA methylation and breast cancer, and support a role for AIMS as a rapid, affordable screening method to identify environmentally induced DNA methylation changes that occur in tumourigenesis.

Keywords: amplification of intermethylated sites, 5-azacytidine, benzo(a)pyrene, breast cancer, DNA methylation

\section{Introduction}

DNA methylation is essential for growth and development, as well as for the environmental responsiveness of mammalian cells. Cellular processes such as $\mathrm{X}$ chromosome inactivation [1], imprinting [2], tumour suppressor inactivation [3], and the silencing of retroviral and transposable DNA elements [4] have been shown to involve DNA methylation. The broad functionality of DNA methylation in mammalian cells validates the need for tight regulation of this process. Approximately $70 \%$ of $\mathrm{CpG}$ dinucleotides in human DNA are constitutively methylated, whereas most of the unmethylated $\mathrm{CpG}$ s are located in so-called $\mathrm{CpG}$ islands, within which lie the promoters of transcribed genes [5]. These unmethylated gene promoter regions are associated with an open chromatin configuration and transcriptional activation [6].

Aberrant DNA methylation can disrupt cellular functions that are essential for normal cell development in several ways. Hypermethylation of tumour suppressor gene promoter regions can lead to transcriptional inactivation and the loss of protein expression [3,7-9]. Also, hypomethylation of the global genome can lead to genomic instability that is exemplified by misalignments, DNA breakage, deletions and duplications during DNA replication, as seen in ICF (immunodeficiency, centromeric region instability, and facial anomalies) syndrome and colorectal cancer $[8,10]$. Finally, DNA methylation is linked to tumourigenesis 
through mutational gene inactivation [9]. Deamination of the methylated cytosine in $\mathrm{CpG}$ dinucleotides can lead to cytosine to thymidine transitions and premature stop mutations, which in turn lead to the inactivation of tumour suppressor genes such as $p 53$ and $L D L$ receptor [11].

In recent years a large body of evidence has been generated that provides a link between aberrant DNA methylation and breast cancer. Such promoter hypermethylation has been shown to inhibit expression of genes such as tumour suppressors BRCA1, E-cadherin, and $p 16^{1 \mathrm{NK} 4 \mathrm{~b}}[7,12,13]$, and steroid receptors $E R \alpha, P R$, and $R A R \beta 2$ [14-16]. Recent reports $[17,18]$ showed that in some breast cancers $A H R I$ (a normally maternally imprinted tumour suppressor gene from the Ras superfamily) can have its paternal copy inactivated through promoter hypermethylation. In addition, global hypomethylation and satellite DNA hypomethylation [19] has been observed in breast cancer. High-performance liquid chromatography analysis of global cytosine methylation revealed a $56 \%$ reduction in breast tumours as well as a $47 \%$ reduction in breast carcinoma cell lines as compared with normal tissue [20]. Interestingly, analysis of ductal breast carcinomas showed loss of heterozygosity due to chromosome 17 deletions in $70 \%$ of tumours analyzed, and chromosome 16 deletions in $66 \%$ of tumours analyzed [21]. In a similarly designed study [10], deletions in ductal breast carcinomas were detected on chromosomes $16 q, 17 p$ and $17 q$, as well as $8 p$ and $13 q$.

Given this information, we felt that an improved understanding of the interplay between changes in methylation and breast carcinogenesis would provide additional insight into the potential cause and effect relationship between these two processes. Much of our current understanding comes from studies of methylation-modifying chemical agents, notably the nucleoside analogue 5-azacytidine. Early studies conducted in mouse embryonic cells [22] identified 5-azacytidine as a differentiating agent that induces muscle cell development, along with the global loss of DNA methylation. During DNA replication, incorporated 5-azacytidine irreversibly binds DNA methyltransferase (DNMT)1, which prevents maintenance methylation on site while depleting available cellular DNMT1, and creates cytotoxic DNA adducts [23,24]. Depletion of DNMT1 causes DNA replication to proceed, with progressive loss of methylation. 5-Azacytidine-induced hypomethylation affects global DNA as well as CpG islands in gene promoters, where it is often associated with transcriptional upregulation [25]. There is a lengthening list of tumour-specific, methylation-repressed genes that are reported to be reactivated by 5 -azacytidine or 5-aza-deoxycytidine, including $E R \alpha$ [26], hMLH1 [27] and P16 [28,29]. Treatment of breast carcinoma cell lines with 5 -azacytidine induces loss of promoter methylation and transcriptional upregulation of $B R C A 1$ - a tumour suppressor gene that is critically impor- tant in the aetiology of hereditary and sporadic breast cancers [30].

Chronic and/or acute exposure to environmental carcinogens can alter normal patterns of methylation tagging and induce wide-ranging destabilizing changes in gene expression patterns that lead to cell transformation and tumourigenesis. One such environmental carcinogen is benzo(a)pyrene $(\mathrm{B}[\mathrm{a}] \mathrm{P})$, which is a polycyclic aromatic hydrocarbon that is present in the cigarette smoke [31], charcoal broiled food [32] and petroleum byproducts [33]. $\mathrm{B}(\mathrm{a}) \mathrm{P}$ and its cellular metabolite (B[a]P-7,8-hydrodiol-9,10epoxide) initiate a range of toxic effects. Analyses of the mutational hot spots in the $p 53$ gene revealed $B(a) P$ adduct formation [34]. B(a)P exposure of MCF-7 breast carcinoma cells causes changes in expression of tumour suppressor genes, particularly a decrease in BRCA1 expression and an increase in $p 53[35,36]$. Finally, some earlier studies showed that cells exposed to $B(a) P$ in tissue culture exhibit a $12 \%$ loss of methylated cytosines [37], and that $\mathrm{B}(\mathrm{a}) \mathrm{P}$ can inhibit methyltransferase activity in vitro [38]. Recent advances in our understanding of epigenetics, and the availability of new analytical tools have set the stage for further analysis of the potential interplay between environmental exposure and methylation in the context of breast cancer.

A unique methylation profiling technique called amplification of intermethylated sites (AIMS) has recently been shown to generate easily readable fingerprints that represent the investigated cell line's methylation profile [39]. This novel protocol is based on the differential cleavage of DNA with methylation-specific isoschisomeric restriction endonucleases. The resulting differentially displayed bands can be excized and used for sequencing analysis. Our modification of this protocol allows for the study of the effect of chemical exposure on DNA methylation in tissue culture models. The objective of the study was to analyze the effect of 5-azacytidine on DNA methylation in breast carcinoma cell lines, both globally using AIMS and specifically using sequence analysis. Also, we verified the use of AIMS as a tool for analysis of chemical exposure within the context of the epigenetics of breast cancer following benzopyrene treatment.

We demonstrated both unique and reoccurring sites of genomic hypomethylation in four breast carcinoma cell lines treated with 5-azacytidine. Comparison of treated versus control samples revealed individual bands that exhibited methylation changes that coincide with susceptible target regions previously associated with chromosome breakage, rearrangement and gene amplification. Similarly, hypomethylation responses following $\mathrm{B}(\mathrm{a}) \mathrm{P}$ treatment reinforce a link between environmental exposures, hypomethylation and breast cancer. 


\section{Methods \\ Cell culture}

MCF-7 and HCC1806 (from American Type Culture Collection) human breast carcinoma cell lines were grown in $150-\mathrm{mm}$ plates in Dulbecco's modified Eagle's medium (Invitrogen, Burlington, ON, Canada) supplemented with Lglutamine $(200 \mathrm{mmol} / \mathrm{l})$, HEPES $(10 \mathrm{mmol} / \mathrm{l})$, penicillin $(100 \mu \mathrm{g} / \mathrm{ml})$, streptomycin $(100 \mu \mathrm{g} / \mathrm{ml})$ and $10 \%$ foetal bovine serum. MDA-MB-231 and MDA-MB-468 human breast carcinoma cell lines were grown in Dulbecco's modified Eagle's medium- $\alpha$. The cells were maintained in a humidified incubator at $37^{\circ} \mathrm{C}$ with $5 \%$ carbon dioxide.

\section{Chemical treatments}

The cells are grown to $10-15 \%$ confluence before treatment with $1 \mu \mathrm{mol} / / 5$-azacytidine in $\mathrm{ddH}_{2} \mathrm{O}$ or with $5 \mu \mathrm{mol} /$ $\mathrm{I} \mathrm{B}(\mathrm{a}) \mathrm{P}$ in dimethyl sulphoxide. DNA was isolated at 48,72 and 96 hours after treatment using DNAZOL Reagent (Gibco BRL, Life Technologies, Burlington, ON, Canada), as per the manufacturer's instructions.

\section{Amplification of intermethylated sites}

Cellular DNA methylation profile analysis was adapted from the AIMS protocol [39]. Briefly, 1-2 $\mu$ g genomic DNA was digested with $20 \mathrm{U}$ of the methylation-sensitive restriction endonuclease Smal (Amersham Biosciences, Baie d'Urfe, PQ, Canada), leaving a blunt end. Subsequently, the DNA was digested with $4 \mathrm{U}$ of the methylation-insensitive isoschisomer PspAI (Stratagene, La Jolla, CA, USA), leaving a staggered end to which a specific adaptor was ligated. Following both digestions and the adaptor ligation reaction, the DNA was purified using the QIAquick ${ }^{\circledR}$ PCR Purification Kit (Qiagen, Mississauga, ON, Canada). Adaptors MCF (5'-CCGGTCAGAGCTTTGCGAAT-3') and BLUE (5'-ATTCGCAAAGCTCTGA-3'), adaptor-specific PCR primers (5'-BLUE-CCGGG-TGG-3' + 5'-BLUECCGGG-TCA-3') and PCR conditions were used as previously described [39]. The DNA samples were run on SequaGel-6 acrylamide gels (National Diagnostics; purchased from Diamed, Mississauga, ON, Canada), and bands were visualized using MR film (Amersham Biosciences) following 48-72 hours of exposure.

The bands that were used for sequence analysis were located on the gel using the positional overlap from the developed X-ray film, and then dissected from the gel and rehydrated in $50 \mu \mathrm{lddH_{2 }}$ O. Following the PCR amplification using the original primers and PCR conditions, the products were ligated into PGEMT-Easy vector (Promega; purchased from VWR Canlab, Mississauga, ON, Canada) and cloned using Top 10 Competent cells (Amersham Biosciences). Positive colonies were checked using EcoRl restriction digests and grown in LB media overnight. The insert-containing vectors was purified using GenElute Plasmid Miniprep Kit (Sigma-Aldrich, Oakville, ON, Canada) and sequenced at the London Regional Genome Centre, London, Ontario, Canada. The sequence homologies were analysed using BLAST [40], which was followed by analysis using Human Genome Browser software [41].

\section{Sodium bisulfite sequencing}

Total genomic DNA was isolated from human breast carcinoma cell lines using DNAzol Reagent (Gibco BRL). We used the sodium bisulfite protocol $[42,43]$ to confirm the methylation status of cytosines within the $\mathrm{CpG}$ island of a band localized to chromosome 2 (2p24; PubMed accession RP11-414D15). This band has been shown to become hypomethylated after 4 days of $1 \mu \mathrm{mol} / / 5$-azacytidine treatment using the AIMS protocol. Briefly, $2 \mu \mathrm{l}$ (approximately $1 \mu \mathrm{g}$ ) genomic DNA was immobilized in $9 \mu \mathrm{l}$ $2 \%$ low melting point agarose beads. Following sodium hydroxide denaturation, the DNA was sodium bisulfite converted and desulfonated. The beads were washed in $1 \times \mathrm{TE}$ and used directly for PCR.

The following nested sets of converted PCR primer oligonucleotides used to amplify this chromosome 2 region were synthesized by Sigma: outside forward primer, 5'TGGAGTAGAAAATATGGTT AGGAATATTGG-3'; outside reverse primer, 5'-CACTCACAACATCTAAAACTACAAA CAACC-3'; inside forward primer, 5'TGGTGTTTTAGATGATGGTAGTGGG-3', and inside reverse primer, 5'-ACAATAACATTCCTTCCTCCAC-3'.

The amplification conditions were five cycles at $94^{\circ} \mathrm{C}(45$ s), $55^{\circ} \mathrm{C}(2 \mathrm{~min})$ and $72^{\circ} \mathrm{C}(2 \mathrm{~min})$, followed by 30 cycles at $94^{\circ} \mathrm{C}(45 \mathrm{~s}), 55^{\circ} \mathrm{C}(1 \mathrm{~min})$ and $72^{\circ} \mathrm{C}(1 \mathrm{~min})$ using Taq polymerase (Invitrogen). A final $10 \mathrm{~min}$ extension time at $72^{\circ} \mathrm{C}$ was also performed. The first PCR amplified converted DNA beads using the outside set of nested primers. The product was then diluted $10 \times$ and $1 \mu \mathrm{l}$ was used as a template DNA for the second PCR using the inside set of primers. All PCR products were cloned using the $p-G^{-} M^{\circledR}$. $T$ Easy Vector System I (Promega). Individual positive clones were identified, and plasmid DNA was isolated by GenElute $^{\mathrm{TM}}$ Plasmid Miniprep Kit (Sigma) and manually sequenced using the T7 Polymerase Sequencing Kit (Amersham Biosciences). The inside forward primer was used in the sequencing reactions and the products were run on $6 \%$ denaturing polyacrylamide gels, dried and exposed to Biomax MR film (Amersham Biosciences) for 24 hours.

\section{Results}

To analyze the effects of 5-azacytidine on global methylation patterns, four breast carcinoma cell lines - MCF-7, MDA-MB 468, HCC1806, and MDA-MB 231 - were grown in media supplemented with $1 \mu \mathrm{mol} / \mathrm{l} 5$-azacytidine for 48,72 and 96 hours. The AIMS method was used to generate easily readable fingerprints representing the cells' 
Figure 1

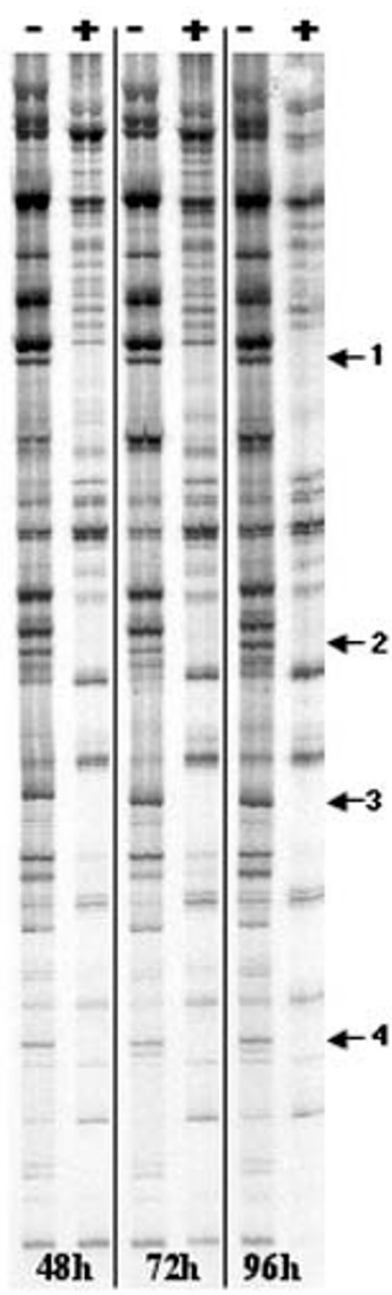

(a) MCF7

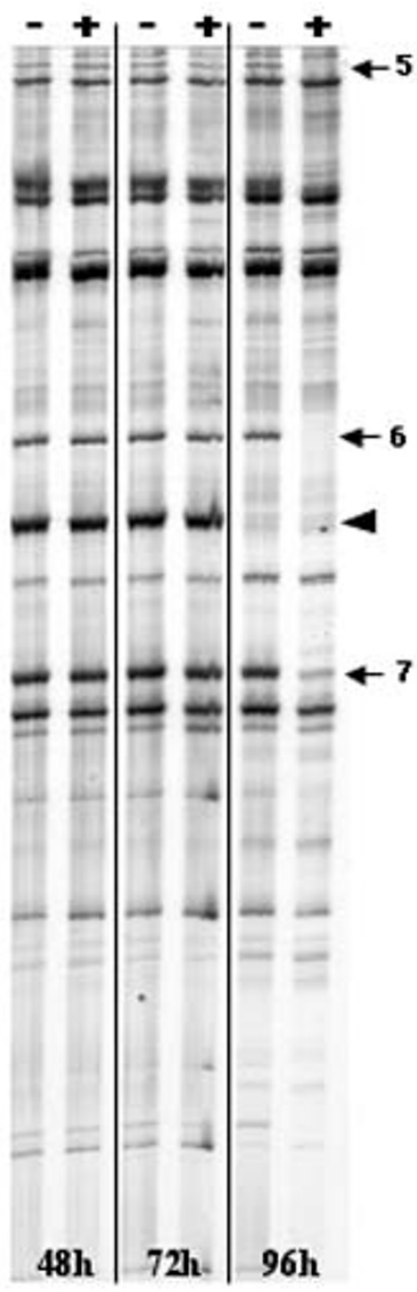

(b) $\mathrm{HCC} 1806$

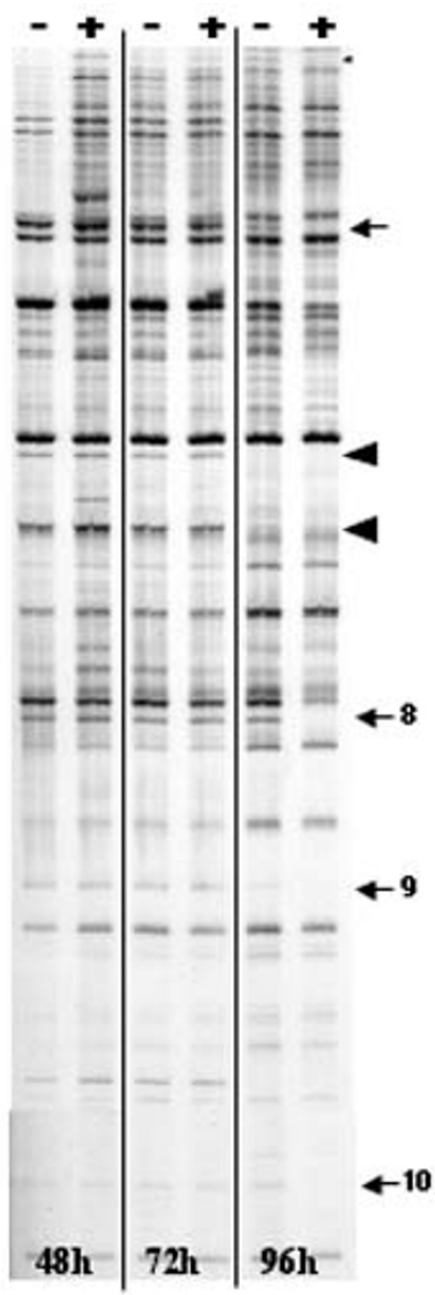

(c) MDA-MB231

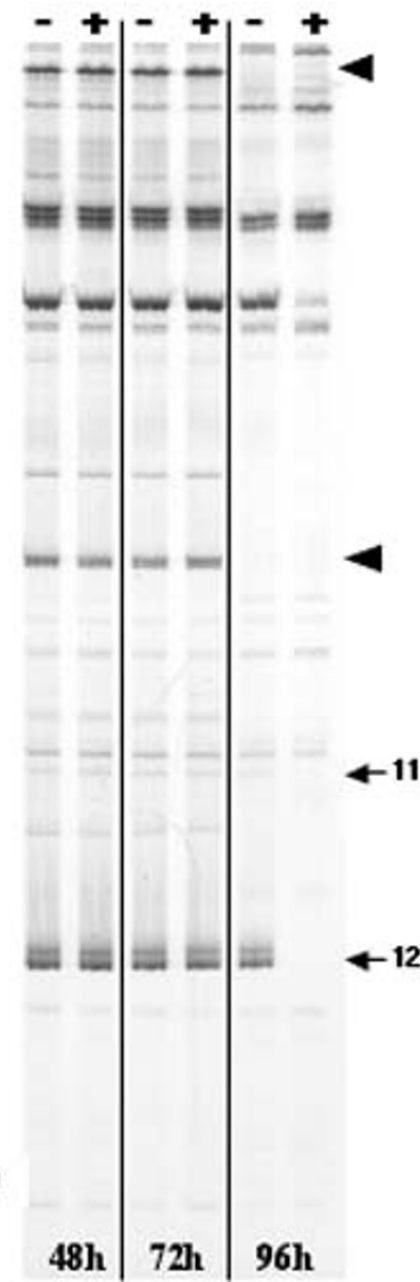

(d) MDA-MB468

Fluorogram of amplification of intermethylated sites (AIMS) gel showing human breast cancer cell lines treated with $1 \mu$ mol// 5-azacytidine for 48,72 and 96 hours (+): (a) MCF-7, (b) HCC1806, (c) MDA-MB231 and (d) MDA-MB468. Profiles of bands from different experiments are highly reproducible with any particular cell line, whereas banding patterns of individual cell lines vary considerably. Banding patterns differ as the culture period is extended, reflecting increased hypomethylation of genomic DNA. Arrows indicate decreases in or loss of band intensity, which are indicative of hypomethylation. The numbered bands are those that were excized, further characterized and localized to specific sites in the genome (see Table 1). Arrowheads indicate loss of bands and hypomethylation that is apparently dependent on culture conditions.

methylation profiles, based on the differential cleavage of DNA with methylation-specific isoschisomeric restriction endonucleases. The loss of DNA methylation at the restriction enzyme recognition sequence results in the bluntended Smal cut, disabling ligation of the adaptor to this DNA fragment. This prevents the adaptor-specific PCR amplification, ultimately leading to the loss of a band on the AIMS gel.

We were able to clearly differentiate and isolate approximately 50 different bands on a single AIMS gel. The number of bands showing hypomethylation compared with the number of unaffected bands differed among the cell lines (Fig. 1), but in all experiments the results were reproducible for each particular cell line and treatment regimen (data not shown). The arrows in Fig. 1 indicate a loss of bands due to hypomethylation in the 5-azacytidine-treated cell lines. In MCF-7 cells this effect was evident after 48 hours (Fig. 1a), whereas the other three cell lines exhibited treatment-associated loss of bands after 96 hours. Interestingly, MCF-7 cells under our experimental conditions exhibited the shortest doubling time of the cell lines tested.

We were able to calculate the degree of hypomethylation for each of the cell lines (Table 1), as indicated by the loss of intense bands in treated versus nontreated cells shown 
Table 1

\begin{tabular}{llll} 
5-Azacytidine induced hypomethylation analysis in the breast carcinoma cells & & \\
\hline Cell line & Time point & Number of intense bands & \% Hypomethylation \\
\hline MCF-7 & 48 hours & 41 & 43.90 \\
& 72 hours & 41 & 43.90 \\
& 96 hours & 41 & 53.65 \\
HCC1806 & 48 hours & 23 & 0 \\
& 72 hours & 23 & 0 \\
MDA-MB 231 & 96 hours & 22 & 36.36 \\
& 48 hours & 29 & 0 \\
MDA-MB 468 & 72 hours & 29 & 0 \\
& 96 hours & 26 & 11.53
\end{tabular}

The number of intense bands as observed is indicated for the nontreated lanes of each cell line from Fig. 1 at each time point. The percentage hypomethylation for each cell line at each time point is shown as percentage loss of bands compared with the corresponding nontreated lane.

in Fig. 1. A progressive loss of methylation (43\%) was evident in MCF- 7 cells as early as 48 hours after treatment that increased up to $54 \%$ at 96 hours. Hypomethylation events were also seen in the other three cell lines but only at the 96-hour time point, and the number of events was less than with the MCF-7 cells. In Fig. 1b,1c,1d (arrowheads), we also observed a number of hypomethylation events not associated with exposure to 5-azacytidine, as signified by the loss of bands in both treated and untreated cells. Interestingly, this effect was seen after 96 hours, when confluence of the cells in the culture was close to $100 \%$.

The arrows in Fig. 1 (1-12) indicate the bands showing 5azacytidine-induced hypomethylation that were later excized and used for sequence analysis. The bands targeted for sequencing were excized from the dried gels, rehydrated, PCR amplified and cloned. The clones ranged between 107 and 481 nucleotides in length and were characterized for their genomic location, BLAST homology and localization within genes or repetitive DNA elements (Table 2). The identities of most individual bands were either unique to a particular cell line, or in some cases the bands represented sequences that were common to more than one cell line. For example, bands 1 and 4 were unique to the MCF- 7 line whereas band 3 in MCF- 7 cells was identical to those sequenced, isolated and characterized from MDA-MB 231 and MDA-MB 468 cells (bands 8 and 11). The 12 bands were mapped to locations throughout the genome, including chromosomes 2, 7, 9, 10, 11 and 21. Using the BLAST homology results [40] and human genome browser software [41], some bands were localized within known gene sequences (band 2, 3, 6, 8, 9, 11, or 12 ) or within repetitive DNA elements (band 5). Bands 1 , 4,7 and 10 did not map to any known genes.

To verify that the loss of a band visualized using the AIMS protocol was due to loss of methylation at Smal/PspAl sites, we performed sodium bisulfite sequencing of 5-azacytidine treated versus untreated cells using primers specific to the DNA sequence represented in band 2 (Table 1). All of the PCR clones were isolated and sequenced, and all clones from the untreated cells exhibited DNA methylation. In contrast, the treated cells produced a mixed population of clones, with six out of 10 clones analyzed exhibiting a clear loss of methylation at the restriction enzyme cut site (Fig. 2).

After establishing that AIMS provides sensitive and reproducible results with the known demethylating agent 5-azacytidine, we analyzed the effect of the known environmental carcinogen B(a)P. The MCF-7 and MDA-MB 231 cell lines were treated with $5 \mu \mathrm{mol} / \mathrm{I} \mathrm{B}(\mathrm{a}) \mathrm{P}$ for 48,72 and 96 hours (Fig. 3). The changes in banding patterns were most evident after 96 hours. Arrows indicate the loss of methylation caused by $B(a) P$ treatment. At the 96 -hour time point, several hypomethylation events were also evident in both treated and untreated cells (arrowheads), perhaps due to cell culture conditions as the cells neared $100 \%$ confluence.

\section{Discussion}

AIMS is a novel protocol that was initially developed as a screening tool for global methylation patterns, in the analy- 
Table 2

\begin{tabular}{|c|c|c|c|c|c|c|}
\hline $\begin{array}{l}\text { Cell line/ } \\
\text { band }\end{array}$ & $\begin{array}{l}\text { Band } \\
\text { size }\end{array}$ & Location & BLAST homology (region) & Gene(s) & Details & Tissue/tumour type \\
\hline \multicolumn{7}{|l|}{ MCF-7 } \\
\hline 1 & 395 & $7 p 14.3$ & RP11-162O1 (61998-61604) & None & NA & NA \\
\hline 2 & 297 & $2 \mathrm{p} 24.1$ & RP11-414D15 (178657-178361) & BC013982, AL834515 & mRNA (UP) & $\begin{array}{l}\text { Choriocarcinoma, } \\
\text { melanoma }\end{array}$ \\
\hline 3 & 183 & $9 q 34.3$ & RP11-413M3 (36274-36092) & AF032387 & $\begin{array}{l}\text { snRNA activating } \\
\text { protein }\end{array}$ & $\begin{array}{l}\text { Foetal cell } \\
\text { teratocarcinoma }\end{array}$ \\
\hline 4 & 107 & $21 q 22.1$ & AP001713 (9409-9303) & None & NA & NA \\
\hline \multicolumn{7}{|c|}{ HCC1806 } \\
\hline 5 & 481 & $9 q 31.2$ & RP11-438P9 (61700-61218) & MIRb & SINE repeat & NA \\
\hline 6 & 297 & $2 \mathrm{p} 24.1$ & RP11-414D15 (178657-178361) & BC013982, AL834515 & mRNA (UP) & $\begin{array}{l}\text { Choriocarcinoma, } \\
\text { melanoma }\end{array}$ \\
\hline 7 & 197 & $11 q 13.3$ & RP11-211G23 (138454-138261) & None & NA & NA \\
\hline \multicolumn{7}{|c|}{ MDA-MB 231} \\
\hline 8 & 183 & $9 q 34.3$ & RP11-413M3 (36274-36092) & AF032387 & $\begin{array}{l}\text { snRNA activating } \\
\text { protein }\end{array}$ & $\begin{array}{l}\text { Foetal cell } \\
\text { teratocarcinoma }\end{array}$ \\
\hline 9 & 156 & $11 q 13$ & CTD-3074O7 (121538-121383) & M86407, AK125851 & $\alpha$-actinin 3 & Foetal skeletal muscle \\
\hline 10 & 122 & $10 q 26$ & RP13-137A17 (59898-60011) & None & NA & NA \\
\hline \multicolumn{7}{|c|}{ MDA-MB 468} \\
\hline 11 & 183 & $9 q 34.3$ & RP11-413M3 (36274-36092) & AF032387 & $\begin{array}{l}\text { snRNA activating } \\
\text { protein }\end{array}$ & $\begin{array}{l}\text { Foetal cell } \\
\text { teratocarcinoma }\end{array}$ \\
\hline 12 & 156 & $11 q 13$ & CTD-3074O7 (121538-121383) & M86407, AK125851 & $\alpha$-actinin 3 & Foetal skeletal muscle \\
\hline
\end{tabular}

sis of tumour samples [39]. Our laboratory has adopted this protocol for the methylation analysis of chemical exposure in breast cancer cell lines. We used the established DNA hypomethylation agent 5-azacytidine [22-24] to prove the effectiveness and reproducibility of the protocol in tissue culture. In our hands the AIMS protocol permitted identification of bands ranging in size from 107 to 481 nucleotides, which could later be isolated, cloned and sequenced. This broad range of sizes allows for analysis of many bands from a single AIMS gel. Bands showing differential display between the untreated and treated cells represent specific sequences throughout the genome that become hypomethylated at the restriction sites. This technique is an effective way to access the global effect on methylation of chemical treatment in cell culture. In cases in which the sequence of a band overlaps with a gene or other potentially interesting region, a more specific technique such as sodium bisulfite sequencing can be used for further analysis.
Four breast carcinoma cell lines - MCF-7, 1806, MDA-MB 231 and MDA-MB 468 - were used in our analyses. The identical band profiles between different time points of the untreated cells in a specific cell line indicate the high reproducibility of the protocol (Fig. 1). For example, MCF-7 cells have identical band patterns between the untreated samples at all three time points. This is also the case in other three cell lines with the exception of some individual bands at the 96-hour time point, as indicated by arrowheads. A possible reason for this treatment-independent hypomethylation might involve changes in the cell culture conditions as the cells approach $100 \%$ confluence at the 96 -hour time point. Changes in environmental conditions often result in altered patterns of gene expression, which has in many cases been associated with methylation-associated chromatin rearrangements [44].

To establish the validity of AIMS protocol we used sodium bisulfite sequencing to verify that the loss of the band on 
Figure 2

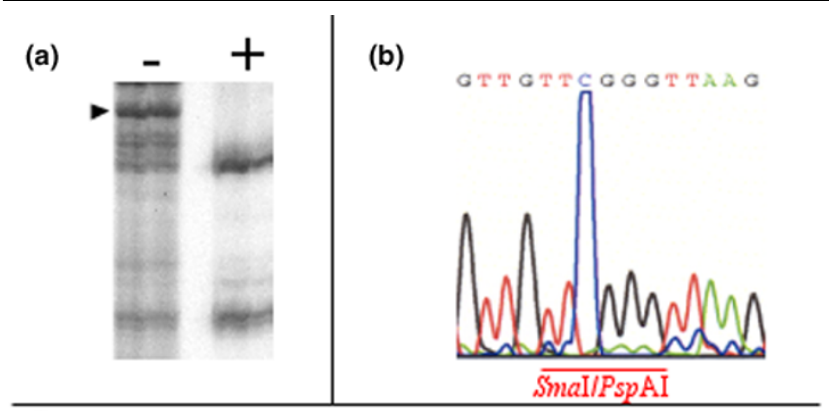

(c)

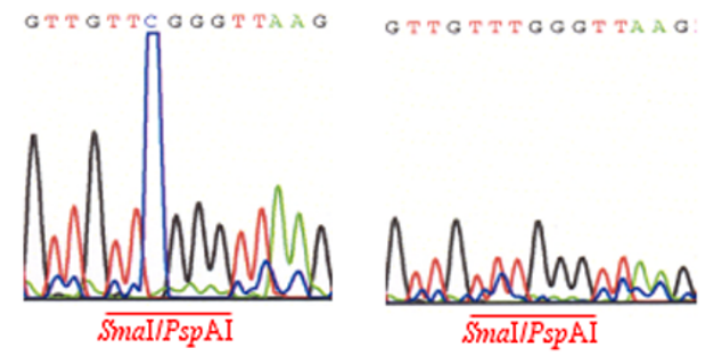

Sodium bisulfite verification of amplification of intermethylated sites (AIMS) protocol. (a) AIMS gel of untreated (-) MCF-7 cells and cells cultured in the presence (+) of $1 \mu \mathrm{mol} / \mathrm{l} 5$-azacytidinecytidine for 96 hours. Arrow indicates the band that was excised, cloned and sequenced following sodium bisulfite analysis. The methylation status of the Smal/PspAl restriction enzyme site was confirmed by sequencing the sodium bisulfite converted DNA from the (b) control and (c) 1 $\mu \mathrm{mol} / \mathrm{l}$ 5-azacytidine-treated MCF-7 DNA cells.

the AIMS gel represents the loss of methylation at the Smal/PspAl cut site. The sequence corresponding to band 2 at 2 p24.1 was analyzed in MCF-7 cells at the 96-hour time point. All of the clones isolated from the untreated cells exhibited methylation at the central cytosine of the restriction site, characterized by its insensitivity to the conversion with sodium bisulfite (Fig. 2b). In contrast, in the 5azacytidine-treated cells there was a mixed population of converted and unconverted clones, indicating a loss of methylation at this site (Fig. 2c). This result is indicative of variable methylation of one of the two Smal/PspAl restriction enzyme sites within this template. The gradual process of demethylation occurring during prolonged exposure to 5 -azacytidine in culture leads to an increased number of sites for Smal digestion over time. This creates blunt ends that prevent ligation of the adaptors containing the primer sequences that initiate PCR amplification. In addition, previously methylated sites that become hemimethylated by replication for only one round without maintenance methylation will not be detected as unmethylated in their assay. These bisulfite results thus provide additional insight into the AIMS protocol. As well as being able to detect complete demethylation [39], our results indicate that AIMS is sensitive to decreases in methylation at a particular restriction enzyme cut site, and suggest that global changes in methylation as a response to a chemical treatment in cell
Figure 3

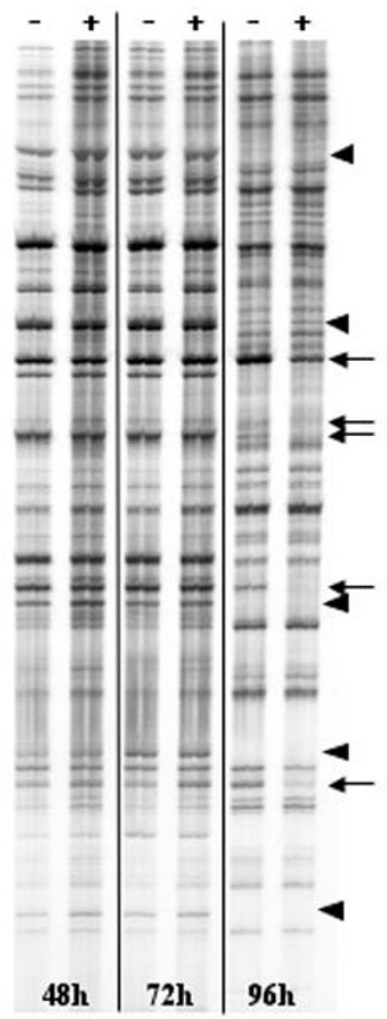

(a) MCF7

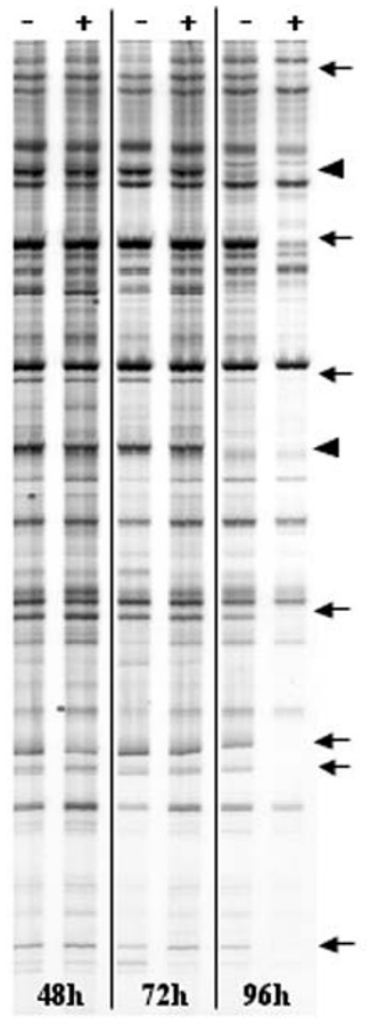

(b) MDA-MB231
Fluorogram of amplification of intermethylated sites (AIMS) gel showing human (a) MCF-7 and (b) MDA-MB 231 breast cancer cells treated with $5 \mu \mathrm{mol} / /$ benzopyrene for 48,72 and 96 hours (+). Banding patterns differ increasingly as the culture period is extended, reflecting increasing hypomethylation of genomic DNA. Arrows indicate decreases in or loss of band intensity, which that are indicative of hypomethylation. Arrowheads indicate loss of bands and hypomethylation that is apparently dependent on culture conditions.

culture can be viewed as a gradual process occurring over successive cell cycles.

We found that some of the hypomethylation events we observed appeared to be targeted to common susceptible sequences in the four cell lines we tested. Bands 3, 8 and 11 are identical, representing sequence located within the SNAP190 gene on 9q34.3 that were recovered from MCF7, MDA-MB 231 and MDA-MB 468 cell line (Table 2). Also, bands 2 and 6 , as well as bands 9 and 12, were identical and were recovered from MCF-7 and 1806, and MDA-MB 231 and MDA-MB 468 cells, respectively. Bands 2 and 6 represent a sequence located within the $B C 013982$ gene, whereas bands 9 and 12 encode sequences within the $\alpha$ actinin 3 gene (AK125851). Furthermore, SNAP190 is found to be expressed in foetal teratocarcinoma cells, whereas BC013982 and AL834515 are mRNAs with 
unknown function that are expressed in choriocarcinoma and melanoma cells, respectively [41].

A previous study of squamous cell carcinomas that analyzed genomic instability using comparative genomic hybridization identified chromosomal regions with significant chromatin rearrangements involving deletions and multiplications [45]. It is interesting to note in the present study that eight out of the 12 bands exhibiting 5-azacytidine-associated hypomethylation in Table 1 belong to regions associated with genomic instability in the squamous cell carcinomas. Specifically, bands 4 and 10 belong to regions that have been shown to be often deleted in squamous cell carcinomas, whereas bands $3,7,8,9,11$ and 12 are located in regions of frequent multiplication. These data suggest that there are regions of the genome that are susceptible to hypomethylation, thereby creating the sites of genomic instability $[19,46]$. Another interesting point to consider relates to the regions that maintain their methylation patterns following 5-azacytidine treatment. Although some of these sequences may escape demethylation by chance, it is possible that the cell may actively act to protect specific sequences from inappropriate demethylation because such a change may result in deleterious consequences for the cell, including inappropriate gene expression or an increased risk for hypomethylation-mediated genomic instability [46]. In any event, the establishment and maintenance of DNA methylation patterns is dynamic and of critical importance in eukaryotic cells.

Finally, to establish the applicability of this technique to the analysis of chemical exposure in tissue culture, we analyzed the effect of the environmental carcinogen benzopyrene on MCF-7 and MDA-MB 231 cells. Our results show the predominant loss of methylation in cells exposed to $5 \mu \mathrm{mol} / \mathrm{l}$ $\mathrm{B}(\mathrm{a}) \mathrm{P}$ at the 96 -hour time point, as indicated by arrows in Fig. 3. These findings are consistent with early studies showing a $12 \%$ decrease in methylation of cells exposed to micromolar $\mathrm{B}(\mathrm{a}) \mathrm{P}$ [37], as well as showing methyltransferase inhibition due to $\mathrm{B}(\mathrm{a}) \mathrm{P}$ exposure in vitro [38]. As with the previous experiments with 5-azacytidine, AIMS is sensitive enough to identify specific changes in DNA methylation that appear to be due to changes in culture conditions or confluency over the duration of the experiments.

\section{Conclusion}

We provide evidence of global hypomethylation effects in multiple breast carcinoma cell lines exposed to 5-azacytidine or benzopyrene. Such hypomethylation may be targeted to a common set of susceptible regions in the genome. The toxic effects of $\mathrm{B}(\mathrm{a}) \mathrm{P}$ in the form of DNA adduct formation, as well as in the modulation of gene expression, are an area of interest in the context of cancer and environmental exposure [34-36]. Our data provide new insight into involvement of aberrant DNA methylation as a target for environmental exposures contributing to breast tumourigenesis and support a role for AIMS as a rapid, affordable screening method with which to identify environmentally induced DNA methylation changes in tumourigenesis.

\section{Competing interests}

None declared.

\section{Acknowledgements}

This work was funded by the Canadian Breast Cancer Research Alliance in a grant awarded to DIR. DTB is the recipient of a CIHR/LRCC postgraduate scholarship.

\section{References}

1. Panning $B$, Jaenisch R: RNA and the epigenetic regulation of $X$ chromosome inactivation. Cell 1998, 93:305-308.

2. $\mathrm{Li} E$, Beard $C$, Jaenisch R: Role for DNA methylation in genomic imprinting. Nature 1993, 366:362-365.

3. Stirzaker C, Millar DS, Paul CL, Warnecke PM, Harrison J, Vincent PC, Frommer M, Clark SJ: Extensive DNA methylation spanning the $\mathbf{R b}$ promoter in retinoblastoma tumors. Cancer Res 1997, 57:2229-2237.

4. Walsh CP, Chaillet JR, Bestor TH: Transcription of IAP endogenous retroviruses is constrained by cytosine methylation. Nat Genet 1998, 20:116-117.

5. Cooper DN, Krawczak M: Cytosine methylation and the fate of CpG dinucleotides in vertebrate genomes. Hum Genet 1989, 83:181-188.

6. Tate PH, Bird AP: Effects of DNA methylation on DNA-binding proteins and gene expression. Curr Opin Genet Dev 1993, 3:226-231.

7. Dobrovic A, Simpfendorfer D: Methylation of the BRCA1 gene in sporadic breast cancer. Cancer Res 1997, 57:3347-3350.

8. Herman JG, Umar A, Polyak K, Graff JR, Ahuja N, Issa JP, Markowitz S, Willson JK, Hamilton SR, Kinzler KW, Kane MF, Kolodner RD, Vogelstein B, Kunkel TA, Baylin SB: Incidence and functional consequences of hMLH1 promoter hypermethylation in colorectal carcinoma. Proc Natl Acad Sci USA 1998, 95:6870-6875.

9. Rice JC, Massey-Brown KS, Futscher BW: Aberrant methylation of the BRCA1 CpG island promoter is associated with decreased BRCA1 mRNA in sporadic breast cancer cells. Oncogene 1998, 17:1807-1812.

10. Radford DM, Fair KL, Phillips NJ, Ritter JH, Steinbrueck T, Holt MS, Donis-Keller $\mathrm{H}$ : Allelotyping of ductal carcinoma in situ of the breast: deletion of loci on 8p, 13q, 16q, 17p and 17q. Cancer Res 1995, 55:3399-3405.

11. Rideout WM III, Coetzee GA, Olumi AF, Jones PA: 5-Methylcytosine as an endogenous mutagen in the human LDL receptor and p53 genes. Science 1990, 249:1288-1290.

12. Graff JR, Herman JG, Lapidus RG, Chopra H, Xu R, Jarrard DF, Isaacs WB, Pitha PM, Davidson NE, Baylin SB: E-cadherin expression is silenced by DNA hypermethylation in human breast and prostate carcinomas. Cancer Res 1995, 55:5195-5199.

13. Herman JG, Merlo A, Mao L, Lapidus RG, Issa JP, Davidson NE, Sidransky D, Baylin SB: Inactivation of the CDKN2/p16/MTS1 gene is frequently associated with aberrant DNA methylation in all common human cancers. Cancer Res 1995, 55:4525-4530.

14. Ottaviano YL, Issa JP, Parl FF, Smith HS, Baylin SB, Davidson NE: Methylation of the estrogen receptor gene $\mathrm{CpG}$ island marks loss of estrogen receptor expression in human breast cancer cells. Cancer Res 1994, 54:2552-2555.

15. Lapidus RG, Ferguson AT, Ottaviano YL, Parl FF, Smith HS, Weitzman SA, Baylin SB, Issa JP, Davidson NE: Methylation of estrogen and progesterone receptor gene $5^{\prime} \mathrm{CpG}$ islands correlates with lack of estrogen and progesterone receptor gene expression in breast tumors. Clin Cancer Res 1996, 2:805-810.

16. Sirchia SM, Ferguson AT, Sironi E, Subramanyan S, Orlandi R, Sukumar S, Sacchi N: Evidence of epigenetic changes affecting 
the chromatin state of the retinoic acid receptor beta2 promoter in breast cancer cells. Oncogene 2000, 19:1556-1563.

17. Yu Y, Fujii S, Yuan J, Luo RZ, Wang L, Bao J, Kadota M, Oshimura $M$, Dent SR, Issa JP, Bast RC Jr: Epigenetic regulation of ARHI in breast and ovarian cancer cells. Ann N Y Acad Sci 2003, 983:268-277.

18. Yuan J, Luo RZ, Fujii S, Wang L, Hu W, Andreeff M, Pan Y, Kadota $M$, Oshimura M, Sahin AA, Issa JP, Bast RC Jr, Yu Y: Aberrant methylation and silencing of ARHI, an imprinted tumor suppressor gene in which the function is lost in breast cancers. Cancer Res 2003, 63:4174-4180.

19. Narayan A, Ji W, Zhang XY, Marrogi A, Graff JR, Baylin SB, Ehrlich $\mathrm{M}$ : Hypomethylation of pericentromeric DNA in breast adenocarcinomas. Int J Cancer 1998, 77:833-838.

20. Esteller M, Fraga MF, Guo M, Garcia-Foncillas J, Hedenfalk I, Godwin AK, Trojan J, Vaurs-Barriere C, Bignon YJ, Ramus S, Benitez J, Caldes T, Akiyama Y, Yuasa Y, Launonen V, Canal MJ, Rodriguez R, Capella G, Peinado MA, Borg A, Aaltonen LA, Ponder BA, Baylin SB, Herman JG: DNA methylation patterns in hereditary human cancers mimic sporadic tumorigenesis. Hum Mol Genet 2001, 10:3001-3007.

21. Vos CB, ter Haar NT, Rosenberg C, Peterse JL, Cleton-Jansen AM, Cornelisse CJ, van de Vijver MJ: Genetic alterations on chromosome 16 and 17 are important features of ductal carcinoma in situ of the breast and are associated with histologic type. $\mathrm{Br} J$ Cancer 1999, 81:1410-1418.

22. Jones PA, Taylor SM: Cellular differentiation, cytidine analogs and DNA methylation. Cell 1980, 20:85-93.

23. Creusot $F$, Acs G, Christman JK: Inhibition of DNA methyltransferase and induction of Friend erythroleukemia cell differentiation by 5-azacytidine and 5-aza-2'-deoxycytidine. J Bio/ Chem 1982, 257:2041-2048.

24. Juttermann R, Li E, Jaenisch R: Toxicity of 5-aza-2'-deoxycytidine to mammalian cells is mediated primarily by covalent trapping of DNA methyltransferase rather than DNA demethylation. Proc Natl Acad Sci USA 1994, 91:11797-11801.

25. Bender CM, Pao MM, Jones PA: Inhibition of DNA methylation by 5-aza-2'-deoxycytidine suppresses the growth of human tumor cell lines. Cancer Res 1998, 58:95-101.

26. Ferguson AT, Lapidus RG, Baylin SB, Davidson NE: Demethylation of the estrogen receptor gene in estrogen receptor-negative breast cancer cells can reactivate estrogen receptor gene expression. Cancer Res 1995, 55:2279-2283.

27. Cameron EE, Bachman KE, Myohanen S, Herman JG, Baylin SB: Synergy of demethylation and histone deacetylase inhibition in the re-expression of genes silenced in cancer. Nat Genet 1999, 21:103-107.

28. Lee YY, Kang SH, Seo JY, Jung CW, Lee KU, Choe KJ, Kim BK, Kim NK, Koeffler HP, Bang YJ: Alterations of p16INK4A and p15INK4B genes in gastric carcinomas. Cancer 1997, 80:1889-1896.

29. Christman JK: 5-Azacytidine and 5-aza-2'-deoxycytidine as inhibitors of DNA methylation: mechanistic studies and their implications for cancer therapy. Oncogene 2002, 21:5483-5495

30. Magdinier F, Billard LM, Wittmann G, Frappart L, Benchaib M, Lenoir GM, Guerin JF, Dante R: Regional methylation of the $\mathbf{5}^{\prime}$ end $\mathrm{CpG}$ island of BRCA1 is associated with reduced gene expression in human somatic cells. FASEB J 2000, 14:1585-1594.

31. Scherer G, Frank S, Riedel K, Meger-Kossien I, Renner T: Biomonitoring of exposure to polycyclic aromatic hydrocarbons of nonoccupationally exposed persons. Cancer Epidemiol Biomarkers Prev 2000, 9:373-380.

32. Lijinsky W: The formation and occurrence of polynuclear aromatic hydrocarbons associated with food. Mutat Res 1991, 259:251-261.

33. Rosenkranz HS: Mutagenic nitroarenes, diesel emissions, particulate-induced mutations and cancer: an essay on cancercausation by a moving target. Mutat Res 1996, 367:65-72.

34. Denissenko MF, Pao A, Tang M, Pfeifer GP: Preferential formation of benzo[a]pyrene adducts at lung cancer mutational hotspots in P53. Science 1996, 274:430-432.

35. Jeffy BD, Chen EJ, Gudas JM, Romagnolo DF: Disruption of cell cycle kinetics by benzo[a]pyrene: inverse expression patterns of BRCA-1 and p53 in MCF-7 cells arrested in S and G2. Neoplasia 2000, 2:460-470.
36. Jeffy BD, Chirnomas RB, Chen EJ, Gudas JM, Romagnolo DF: Activation of the aromatic hydrocarbon receptor pathway is not sufficient for transcriptional repression of BRCA-1: requirements for metabolism of benzo[a]pyrene to $7 \mathrm{r}$,8t-dihydroxy-9t,10-epoxy-7,8,9,10-tetrahydrobenzo[a]pyrene. Cancer Res 2002, 62:113-121.

37. Wilson VL, Jones PA: Inhibition of DNA methylation by chemical carcinogens in vitro. Cell 1983, 32:239-246.

38. Wojciechowski MF, Meehan T: Inhibition of DNA methyltransferases in vitro by benzo[a]pyrene diol epoxide-modified substrates. J Biol Chem 1984, 259:9711-9716.

39. Frigola J, Ribas M, Risques RA, Peinado MA: Methylome profiling of cancer cells by amplification of inter-methylated sites (AIMS). Nucleic Acids Res 2002, 30:e28.

40. National Centre for Biotechnology Information BLAST [http:// www.ncbi.nlm.nih.gov/BLAST.]

41. Human Genome Browser Gateway [http://
] www.genome.ucsc.edu/cgi-bin/hgGateway]

42. Clark SJ, Harrison J, Paul CL, Frommer M: High sensitivity mapping of methylated cytosines. Nucleic Acids Res 1994 22:2990-2997.

43. Olek A, Oswald J, Walter J: A modified and improved method for bisulphite based cytosine methylation analysis. Nucleic Acids Res 1996, 24:5064-5066.

44. Jones PA, Baylin SB: The fundamental role of epigenetic events in cancer. Nat Rev Genet 2002, 3:415-428.

45. Petersen S, Aninat-Meyer M, Schluns K, Gellert K, Dietel M, Petersen I: Chromosomal alterations in the clonal evolution to the metastatic stage of squamous cell carcinomas of the lung. Br J Cancer 2000, 82:65-73.

46. El-Osta A: DNMT cooperativity: the developing links between methylation, chromatin structure and cancer. Bioessays 2003 25:1071-1084. 